\title{
Exposure as Collected Dose
}

National Cancer Institute

\section{Source}

National Cancer Institute. Exposure as Collected Dose. NCI Thesaurus. Code C117479.

The amount of substance that the patient or test subject was exposed to at one time, or the total quantity administered. 